\title{
活性化反応蒸着法による $\mathrm{PbTiO}_{3}$ 薄膜の作製
}

\author{
岡村敏彦・小田喜一*・高田 潤*・尾坂明義* \\ 三浦嘉也*.寺嶋孝仁**. 坂東尚周*** \\ 東ソ一 (株) 新材料研究所第一研究室, 252 綾瀬市早川 2743-1 \\ * 岡山大学工学部精密応用化学科, 700 岡山市津島中 3-1-1 \\ **生産開発科学研究所, 606 京都市左京区下鴨森本町 15 \\ ***京都大学化学研究所, 611 宇治市五ヶ庄
}

\section{Preparation of $\mathrm{PbTiO}_{3}$ Films by Activated Reactive Evaporation (ARE)}

\author{
Toshihiko OKAMURA, Kiichi ODA*, Jun TAKADA*, Akiyoshi OSAKA*, Yoshinari MIURA*, \\ Takahito TERASHIMA** and Yoshichika BANDO***
}

TOSOH Corporation, 2743-1, Hayakawa, Ayase-shi 252

* Department of Applied Chemistry, Faculty of Engineering, Okayama University,

3-1-1, Tsushima-Naka, Okayama-shi 700

** Research Institute for Production Development, 15, Shimogamo Morimoto-cho, Sakyo-ku, Kyoto-shi 606

*** Institute for Chemical Research, Kyoto University, Gokasho, Uji-shi 611

$\mathrm{PbTiO}_{3}$ thin films were prepared by activated reactive evaporation (ARE) through controlling evaporation rates of $\mathrm{Pb}$ and $\mathrm{Ti}, \mathrm{O}_{2}$ pressure, and substrate temperature. The $\mathrm{Pb} / \mathrm{Ti}$ ratio of these films depended on the evaporation rate of $\mathrm{Ti}$. When the substrate temperature and $\mathrm{O}_{2}$ pressure were held at $600^{\circ} \mathrm{C}$ and $1.6 \times 10^{-4}$ Torr respectively, the optimum evaporation rates of $\mathrm{Ti}$ and $\mathrm{Pb}$ for a nearly stoichiometric $\mathrm{PbTiO}_{3}$ film were 0.2 and $1.2-1.8 \AA / \mathrm{s}$, respectively. $\mathrm{PbTiO}_{3}$ films deposited on a c-plane of sapphire showed preferred orientation of (111) plane, and those on (100) plane of $\mathrm{MgO}$ showed strong $c$-axis orientation. AES depth profile mesurements and SEM observations indicated that these films were uniform in composition and dense.

[Received March 14, 1990; Accepted April 13, 1990]

Key-words : Thin film, $\mathrm{PbTiO}_{3}$, Activated reactive evaporation, c-axis orientation

\section{1. 緒 言}

$\mathrm{PbTiO}_{3}, \mathrm{~Pb}(\mathrm{Zr} . \mathrm{Ti}) \mathrm{O}_{3},(\mathrm{~Pb} . \mathrm{La})(\mathrm{Zr} . \mathrm{Ti}) \mathrm{O}_{3}$ 等の $\mathrm{Pb}$ を含むぺロブスカイト型酸化物は, 圧電性, 焦電性, 電 気光学特性を兼ね備えた興味深い材料であり，これらの 特性を利用した種々のデバイスが実用化されてい る $^{1) \sim 6)}$. その中で $\mathrm{PbTiO}_{3}$ は誘電率が小さく, キュリー 温度が $490^{\circ} \mathrm{C}$ と高く, 更に結晶構造の異方性が大きい などの特徴を持ち，それらのセラミックスはポイントセ ンサーとして実用化されている。

近年薄膜化技術の進歩に伴い, デバイスの性能向上の ため $\mathrm{PbTiO}_{3}$ 薄膜の研究も盛んになってきた。飯島らは R.F.ママグネトロンスパッタ法を用いて $c$ 軸に配向した $\mathrm{PbTiO}_{3}$ 薄膜を作製することにより，分極処理をしなく ても自発分極が一方向にそろい, 分極軸となる $c$ 軸方 向において 100 程度の比誘電率が得られたと報告してい $る^{7)}$.このような $c$ 軸配向した $\mathrm{PbTiO}_{3}$ 薄膜は高感度の 焦電材料として期待される. また, 最近電気光学効果を 利用した光変調器, 導波路型光スイッチ, 光メモリ一な
ビが光IC 分野で注目をあびてきており，光散乱の少な い単結晶薄膜の要求が高まってきている。この場合, 緻 密かつ均質な膜の作製が必須となる。このような薄膜を 作製するには基板上への蒸発粒子の供給を精密に制御す る必要がある。スパッ夕法による $\mathrm{PbTiO}_{3}$ などの多元系 酸化物薄膜の作製においては, 組成を化学量論的に制御 するのは難しいうえ, スパッタダメージによって, 膜に 損傷が生じる可能性もある。

活性化反応蒸着法は, 基板温度, 蒸発速度, 酸素圧を 独立に制御できるという特徵を持っており，良質な多元 系酸化物薄膜を得るのに適した方法である。この方法に より, 寺嶋らは良質な $\mathrm{YBa}_{2} \mathrm{Cu}_{3} \mathrm{O}_{\mathrm{Y}}$ の超伝導薄膜を作製 している ${ }^{81,9)}$. 本研究では, 蒸発源毎に独立した水晶振 動子膜厚計によって, 組成を制御できるという特徴を持 つ活性化反応蒸着装置を用いて, $\mathrm{MgO}(100)$ 基板及び サファイア $c$ 面基板上に $\mathrm{PbTiO}_{3}$ 薄膜の作製を試み, 得られた薄膜の組成を蛍光 X線分析により定量的に決定 し, 膜中の組成が化学量論比となるような蒸発条件につ 
いて検討をした. また, 生成膜の結晶性の検討, 組織観 察及び膜の深さ方向の組成分析等のキャラクタリゼ一 ションを試みた。

\section{2. 実験方法}

\section{1 実験装置及び作製条件}

図 1 に本実験で用いた活性化反応蒸着装置（日本電子 製，JST-EB 1000 型）の概略図を示す。蒸発源には Ti 金属 $(99.9 \%), \mathrm{Pb}$ 金属 $(99.9 \%)$ を用いた。 $\mathrm{Ti}$ 金属 の加熱には電子ビーム (日本電子製, JEBG-203 UB 型) を, $\mathrm{Pb}$ 金属の加熱には抵抗加熱（ヒーター：タングス テン,るつぼ：アルミナ）を用いた。また, 各々の蒸発 速度は別々の水晶振動子膜厚計によって独立に制御し た。蒸発した金属原子と基板付近に導入した酸素ガスを 反応させて単結晶基板上に配向膜を形成させた。薄膜の 結晶性と反応性をよくするために，R，F，によって真空 槽内に酸素プラズマを発生させた。本報ではスパッ夕法 などで基板温度 $550^{\circ} \sim 650^{\circ} \mathrm{C}$ において $c$ 軸配向膜を得 たという報告 ${ }^{5)}$ 亿) を参考にして, 基板温度を $600^{\circ} \mathrm{C}$ に選 んだ. 酸素王 $1.6 \times 10^{-4}$ Torr, R.F. 出力 $150 \mathrm{~W}$ の条件 下で $\mathrm{Ti}$ と $\mathrm{Pb}$ の蒸発速度を変化させて蒸着した。ここ で, 蒸発速度は水晶振動子膜厚計に表示された速度であ り，振動子表面での蒸着重量を反映している．基板と膜 厚計の膜厚分布の違いは $\mathrm{Cu}$ 金属によりあらかじめ補正 をした．基板には光学研磨したサファイア $c$ 面及び $\mathrm{MgO}(100)$ 面を用いた. 蒸着後, 酸素ガス供給を止めて, 真空槽内において基板を室温まで冷却した。

\section{2 膜の特性評価}

生成相の同定はX 線回折 (理学電機製 RAD-IA 型, RINT-1000 型， $\mathrm{Cu} K \alpha$ ) により行った。また，薄膜中

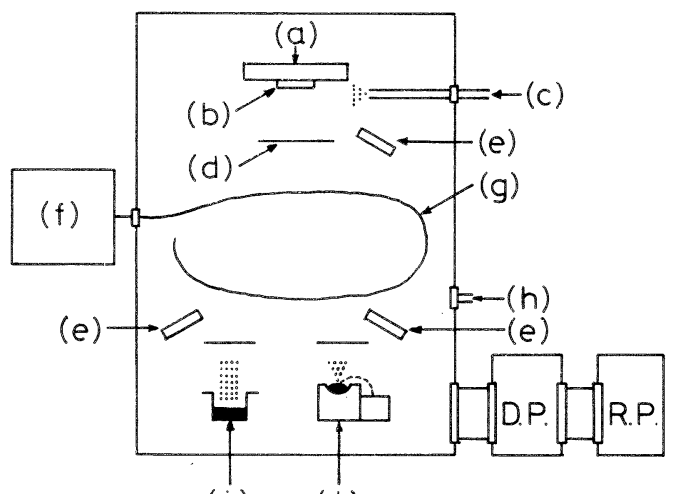

(i) (j)

Fig. 1. Schematic diagram of activated reactive evaporation system.

(a) Substrate heater, (b) Substrate, (c) Oxygen leak valve, (d) Shutter, (e) Crystal monitor, (f) R.F. power supply, (g) R.F. coil, (h) Vacuum gauge, (i) Alumina crucible heated by tungsten wire, (j) Electron beam gun
の金属元素の組成は蛍光 X 線分析装置（理学電機製， 3134 型）により決定した。本研究では $\mathrm{TiO}_{2}$ と $\mathrm{PbO}$ の 種々の組成比の混合粉末を標準試料に用いて定量分析を 行った。粉末と薄膜ではX線の吸収が異なると予測され るが，X線回折より同定した生成相と蛍光 X線分析よ り求めた原子比を比較するとほぼ一致した．膜の深さ方 向の組成変化はオージェ電子分光装置（日本電子製, JAMP-30 型) を, 膜厚は表面粗さ計（東京精密製, Surfcom 1500 A 型) により測定した。 また，走査電子 顕微鏡（SEM; 明石製作所製，DS-130 型）を用いて組 織観察を行った。

\section{3. 結果及び考察}

\section{1 $\mathrm{PbTiO}_{3}$ 薄膜の作製条件の検討}

$\mathrm{PbTiO}_{3}$ 薄膜を作製するに当たって，膜の $\mathrm{Pb}$ と $\mathrm{Ti}$ の組成が化学量論比に合うように蒸発速度を調整する必 要がある. $\mathrm{Pb}$ の蒸発速度を $\mathrm{Ti}$ の蒸発速度の約 2.8 倍 $\left(\mathrm{PbO} / \mathrm{TiO}_{2}\right.$ の重量比) にして蒸着すれば，膜中の $\mathrm{Ti}$ と $\mathrm{Pb}$ の原子比はほぼ $1: 1$ になる。しかし，実際には 蒸気圧の高い $\mathrm{Pb}$ が基板から再蒸発することを考慮にい れて蒸着しなければならない。この $\mathrm{Pb}$ の再蒸発は基板 温度や酸素圧によって変化するので，種々の基板温度及 び酸素圧で $\mathrm{Ti}$ 亡 $\mathrm{Pb}$ の蒸着速度比を求めなければなら ない。本研究では前述したように基板温度 $600^{\circ} \mathrm{C}$, 酸素 圧 $1.6 \times 10^{-4}$ Torr の条件下で， サファイア基板上に蒸 着する場合の最適蒸発速度比について検討した。試みと して, $\mathrm{Pb}$ の蒸発速度を $3 \AA / \mathrm{s}$ に保ち $\mathrm{Ti}$ の蒸発速度を 変化させて, 生成膜の $\mathrm{Ti}$ と $\mathrm{Pb}$ の原子比が $1: 1$ となる ための Ti の蒸発速度について検討した。得られた結果 を図 2 に示す. 図中の縦軸は蛍光 X線分析によって求め た膜中の $\mathrm{Pb}$ の モ分率である。 $\mathrm{Pb}$ の蒸発速度が 3 $\AA / \mathrm{s}$ のとき, $0.4 \AA / \mathrm{s}$ 以上の $\mathrm{Ti}$ の蒸発速度では $\mathrm{TiO}_{2}$ が 優先的に生成し, $\mathrm{Pb}$ の付着はX 線回折及び蛍光 $\mathrm{X}$ 線組 成分析では認められなかった。 Ti の蒸発速度を減少さ せると急激に多量の $\mathrm{Pb}$ が付着し始め, Ti の蒸発速度 $0.3 \AA / \mathrm{s}$ において $\mathrm{Pb}$ のモル分率は約 0.4 であり, 生成

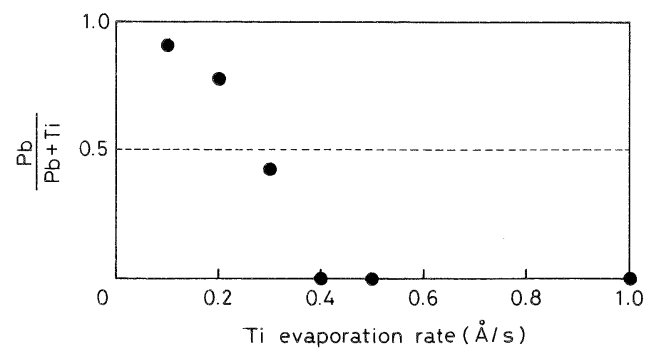

Fig. 2. Relation between $\mathrm{Pb} /(\mathrm{Pb}+\mathrm{Ti})$ ratio and $\mathrm{Ti}$ evaporation rate. $\mathrm{Pb}$ evaporation rate was kept at $3.0 \mathrm{~A} / \mathrm{s}$ (Substrate temperature $: 600^{\circ} \mathrm{C}, \mathrm{O}_{2}$ gas pressure : $1.6 \times 10^{-4}$ Torr) . 


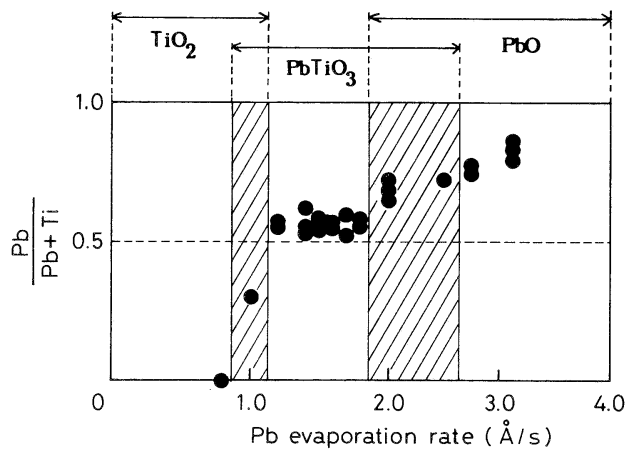

Fig. 3. Relation between $\mathrm{Pb} /(\mathrm{Pb}+\mathrm{Ti})$ ratio and $\mathrm{Pb}$ evaporation rate. Ti evaporation rate was kept at $0.2 \mathrm{~A} / \mathrm{s}$ (Substrate temperature $: 600^{\circ} \mathrm{C}, \mathrm{O}_{2}$ gas pressure : $1.6 \times 10^{-4}$ Torr) .

相は $\mathrm{PbTiO}_{3}$ であった。 $0.2 \AA / \mathrm{s}$ においては約 0.8 であ

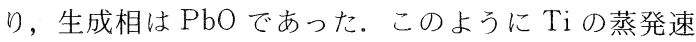
度が組成に微妙に影響を与えるので，Ti の蒸発速度を 更に細かく変化させるのは難しい。そこで Ti の蒸発速 度を $0.2 \AA / \mathrm{s}$ に保ち, $\mathrm{Pb}$ の蒸発速度を変化させて膜中 の $\mathrm{Ti}$ と $\mathrm{Pb}$ の原子比が $1: 1$ となるための $\mathrm{Pb}$ の蒸発速 度について検討した。それらの結果を図 3 に示す。Ti の蒸発速度が $0.2 \AA / \mathrm{s}$ のとき, $\mathrm{Pb}$ の蒸発速度を減少さ せると膜中の $\mathrm{Pb}$ 含有量も減少し, 生成相も $\mathrm{PbO}$ から $\mathrm{PbTiO}_{3}$, 更に $\mathrm{TiO}_{2}$ へ変化した. $\mathrm{Pb}$ の蒸発速度が $1.2 \sim 1.8 \AA / \mathrm{s}$ の範囲内で $\mathrm{Pb}$ のモル分率は約 0.55 と一 定となり，生成相も $\mathrm{PbTiO}_{3}$ の単相で, 膜中の $\mathrm{Ti}$ と $\mathrm{Pb}$ の比がほぼ $1: 1$ になることがわかった。ここで蒸 発速度が $1.2 \sim 1.8 \AA / \mathrm{s}$ と幅を持つのは過剩に飛んで来 た $\mathrm{Pb}$ が，ある程度までは基板から再蒸発するためと考 えられる。この範囲の両端の蒸発速度, すなわち, $\mathrm{Pb}$ の蒸発速度 $1.2 \AA / \mathrm{s}$ と $1.8 \AA / \mathrm{s}$ において得られた膜をX 線回折結果より比較するとほぼ一致し，違いが見られな かった。 また, $\mathrm{Pb}$ かル分率の一定值，すなわち膜中 の $\mathrm{Ti}$ と $\mathrm{Pb}$ の原子比がほぼ $1: 1$ になると予測される蒸 発速度において $\mathrm{Pb}$ のモル分率は 0.55 と若干 $\mathrm{Pb}$ の方 が多い。これは標準試料に粉末を用いたために誤差が生 じたものと考えられる．以上の結果より Ti の蒸発速度 $0.2 \AA / \mathrm{s}$ に対して $\mathrm{Pb}$ の蒸発速度を $1.2 \sim 1.8 \AA / \mathrm{s}$ にする ことによって $\mathrm{Ti}$ と $\mathrm{Pb}$ の比が約 $1: 1$ の膜の得られるこ とが分かった，以上のことをふまえて，後述する膜は基 板温度 $600^{\circ} \mathrm{C}$, 酸素圧 $1.6 \times 10^{-4}$ Torr, $\mathrm{Ti}$ と $\mathrm{Pb}$ の蒸発 速度をそれぞれ $0.2 \AA / \mathrm{s}, 1.2 \AA / \mathrm{s}$ にし，厚さ $0.1 \sim 0.7$ $\mu \mathrm{m}$ に蒸着した膜について検討を加えた。

\section{2 配向性及び組織観察}

サファイア $\mathrm{c}$ 面基板上に $0.5 \mu \mathrm{m}$ 蒸着された膜の深さ 方向の組成分析を行った。図 4 にそのオージェプロファ イルを示す．膜中では $\mathrm{Pb}, \mathrm{Ti}, \mathrm{O}$ が均一に分布してお り膜の深さ方向では組成の変化は少ないと考えられる.

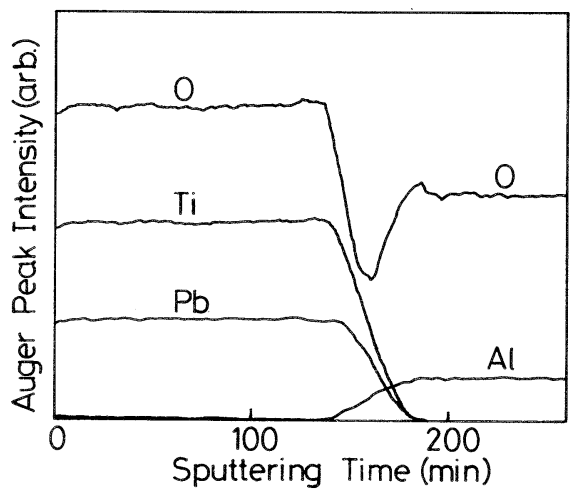

Fig. 4. Auger depth profile of a $\mathrm{PbTiO}_{3}$ film(Substrate temperature $: 600^{\circ} \mathrm{C}, \mathrm{O}_{2}$ gas pressure $: 1.6 \times 10^{-4}$ Torr, thickness : $0.5 \mu \mathrm{m})$.

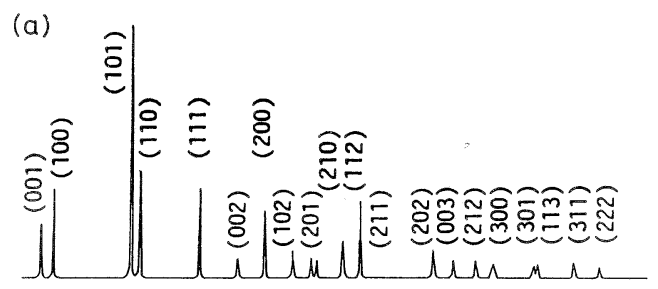

(b)

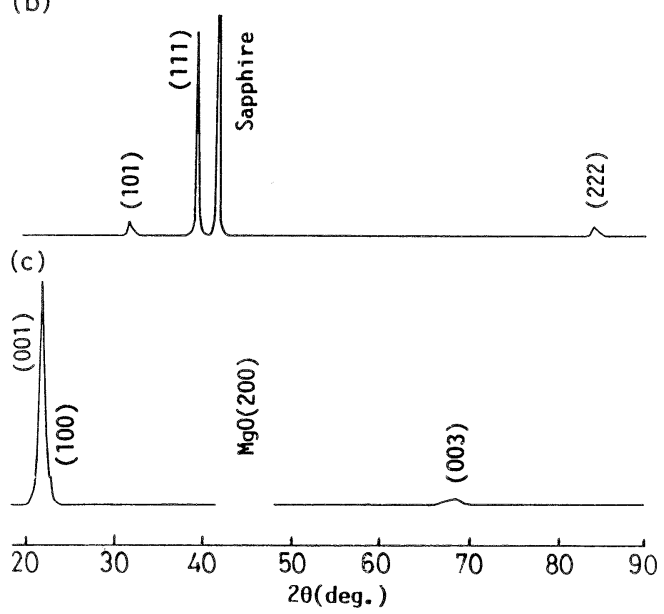

Fig. 5. X-ray diffraction patterns of (a) $\mathrm{PbTiO}_{3}$ powder, (b) film prepared on $c$-plane of sapphire and (c) film prepared on (100) MgO.

図 5 に (a) $\mathrm{PbTiO}_{3}$ 粉末，(b) サファイア $\mathrm{c}$ 面基板上 に作製した薄膜及び (c) $\mathrm{MgO}$ (100) 基板上に作製した 薄膜の X 線回折パターンを示す。(c) の $\mathrm{MgO}$ 基板上の 膜はサファイア $c$ 面基板で求めた最適蒸発速度 $\mathrm{Ti}=$ $0.2 \AA / \mathrm{s}, \mathrm{Pb}=1.2 \AA / \mathrm{s}$ を適応させて作製した。基板に よる組成ずれは考えられるが蛍光 X線組成分析の結果か らは認められなかった。(a) は典型的な多結晶 $\mathrm{PbTiO}_{3}$ のパターンを示している。(b) では $\mathrm{PbTiO}_{3}(111)$ の強 い回折ピークと弱いピーク (101)，(222）が観察される. (c) では $\mathrm{PbTiO}_{3}$ の強い回折ピーク (001) と弱いピ- 
(a) $\mathrm{PbTiO}_{3}$ on $\mathrm{MgO}$

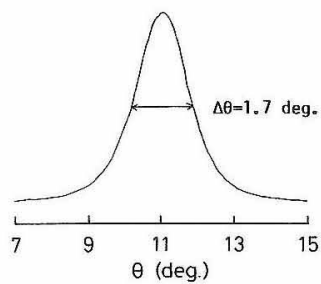

(b) $\mathrm{PbTiO}_{3}$ on sapphire

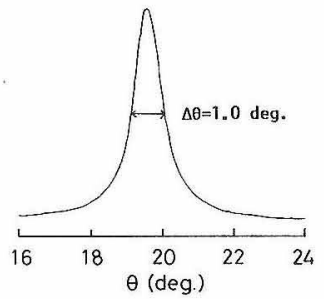

Fig. 6. Rocking curves of (a) (001) peak of $\mathrm{PbTiO}_{3}$ prepared on (100) $\mathrm{MgO}$ substrate and (b)(111) peak of film prepared on c-plane sapphire substrate.

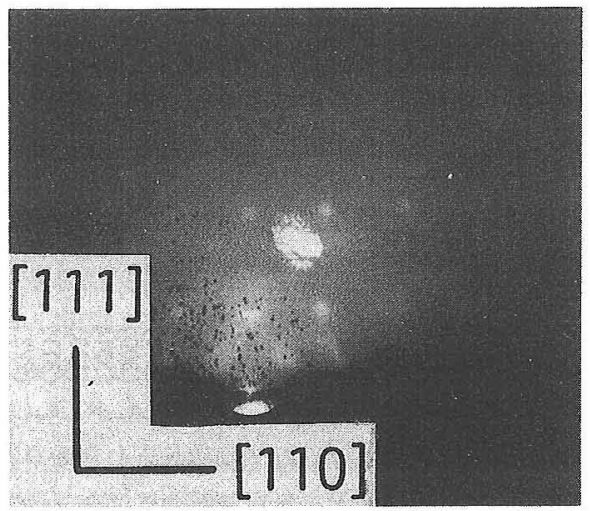

Fig. 7. Reflection electron diffraction patterns of $\mathrm{PbTiO}_{3}$ film prepared on c-plane sapphire.

ク (100)，(003）が锶察される. 図 5 の (b)，(c) よ り観察された強いピーク（111）及び（001）については ロッキングカーブによって結晶性を評価した。それらの 結果を図 6 に示す。ロッキングカーブの半值幅は $\mathrm{PbTiO}_{3}(001)$ で約 $1.7 \mathrm{deg} .,(111)$ 面で約 $1 \mathrm{deg}$.を示 した。一方，基板の $\mathrm{MgO}$ 単結晶及びサファイア単結晶 のロッキングカーブの幅は $1 \mathrm{deg}$. 及び $0.6 \mathrm{deg}$. である ことを考えればこれらの膜の半值幅の值は十分小さいと 考えられ，結晶性は良いと推測される.また，図7に(b) の試料についての高速反射電子線回折 (Reflection electron diffraction, RHEED) パターンを示す.図 5 (b) のX線回折結果及びロッキングカーブの半值幅が約 1 deg. と小さいこと, RHEED パターンでスポットパター ンを示していることにより $\mathrm{PbTiO}_{3}(111)$ 面がサファイ ア c 面基板上にエピタキシャル成長していると判断さ れる.また, $\mathrm{MgO}(100)$ 基板上に蒸着した膜については, 図 5 (c)のX線回折結果より (001) の回折ピークが (100) のそれと比べ著しく強いこと，ロッキングカーブの半值 幅が約 $1.7 \mathrm{deg}$. と小さいことより $c$ 軸に強く配向した 膜であるといえる， $c$ 軸の配向率 $\alpha$ を X 線の回折強度 を用い，式 $\alpha=I(001) /\{I(100)+I(001)\}$ (ここで $I$ (001)，I(100) は $(001) と(100)$ のX線回折強度) に従って計算すると約 0.88 であった. スパッタ法で作
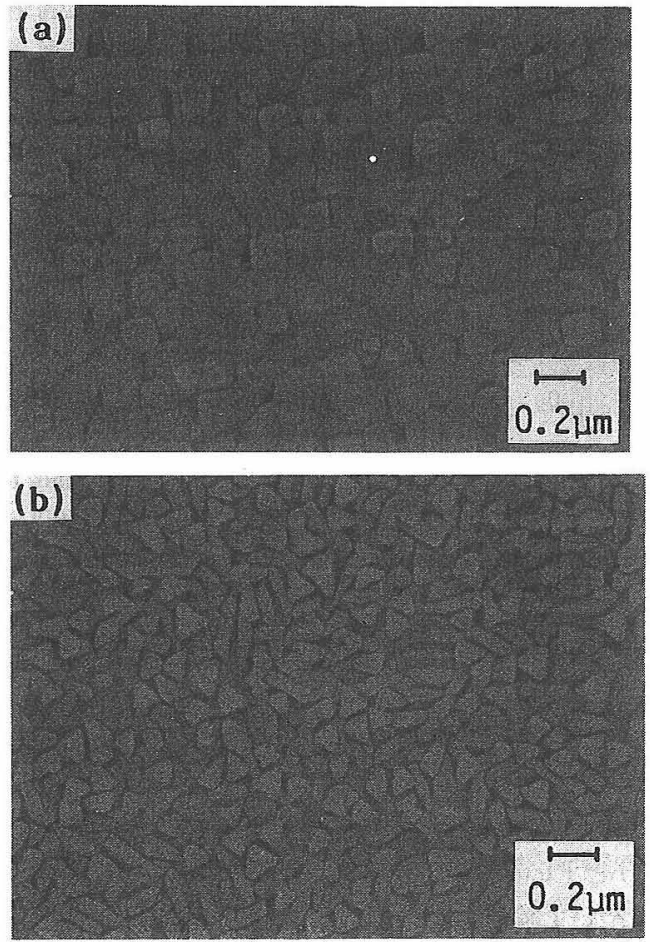

Fig. 8. Scanning electron micrographs of (a) the surface of $\mathrm{PbTiO}_{3}$ film prepared on $(100) \mathrm{MgO}$ substrate and (b) the surface of the film prepared on $c$-plane sapphire substrate.

製した $c$ 軸配向膜7では $0.8 \sim 0.9$ の值が得られており 本研究で得られた值と比較するとほぼ同等の值を示し た。

図 8 (a) は $\mathrm{MgO}(100)$ 基板上に作製した薄膜の表面 のSEM 写真である. 薄膜の表面は一辺がほぼ $0.1 \mu \mathrm{m}$ の正方形をした結晶粒からなっており，この正方形の結 晶粒の方位は $\mathrm{MgO}$ 基板の方位と一致していると考えら れる．平滑性は比較的良く密度も高いと観察される。図 8 （b）はサファイア $\mathrm{c}$ 面基板上に作製した膜の表面の SEM 写真である。薄膜の表面には一辺がほぼ $0.1 \mu \mathrm{m}$ の三角形をした結晶粒と長柱状の結晶粒が観察される. 配向性の良い試料のものほどこの三角形の結晶粒が多い ことより,三角形をした結晶粒は正方晶 $\mathrm{PbTiO}_{3} の(111)$ 面に対応していると予測される，表面の平滑性は若干悪 いが，破面を SEM 観察すると柱状構造はみられず高密 度であった。

\section{4. 総 括}

活性化反応蒸着法により $\mathrm{PbTiO}_{3}$ 薄膜を作製した。基 板温度 $600^{\circ} \mathrm{C}$ において膜中の $\mathrm{Ti}$ と $\mathrm{Pb}$ の原子比がほぼ $1: 1$ となる最適蒸発速度について検討した。それらの 条件下で作製した膜について得られた結果をつぎに要約 する。 
(1) $\mathrm{Ti}$ の蒸発速度が $0.4 \AA / \mathrm{s}$ 以上では $\mathrm{Pb}$ が付着 しない. $\mathrm{Ti}$ の蒸発速度 $0.2 \AA / \mathrm{s}$ に対して $\mathrm{Pb}$ の蒸発速 度を $1.2 \sim 1.8 \AA / \mathrm{s}$ にすることによって膜中の組成がほ ぼ1：1になることが分かった。

（2）蒸発速度を精密に制御することによって膜の深 さ方向において組成ずれの少ない膜を得ることができ た。

（3） $\mathrm{MgO}(100 ）$ 基板上に強く $c$ 軸に配向した $\mathrm{PbTiO}_{3}$ 薄膜を作製することができた。この膜の表面は 一辺がほぼ $0.1 \mu \mathrm{m}$ の正方形をした結晶粒から成り立っ ており, 平滑性もよく高密度のものであった。配向率は ほぼ 0.88 であった。

(4) サファイア $\mathrm{C}$ 面基板上に $\mathrm{PbTiO}_{3}(111)$ のエピ タキシャル膜を作製させた。ロッキングカーブの半值幅 が $1 \mathrm{deg}$ 。程度の結晶性の良いものが得られた。

本報では作製条件及び作製された膜の結晶性等を中心 に記述したが, 今後電気的特性など種々の物性測定を
行っていく予定である.

謝辞本研究は, 文部省科学研究費一般研究 $(A)$ (No.62430016) の援助によって行われた。記して謝意を表しま す.

\section{文献}

1) 田中克彦, セラミックス, 19, 290-95 (1984)。

2）和佐清孝, セラミックス，21，119-25 (1986).

3) K. Wasa, O. Yamazaki, H. Adachi, T. Kawaguchi and K. Setsune, J. Lightwave. Tech., LT-2, 710-14 (1984).

4) T. Kawaguchi, H. Adachi, K. Setsune, O. Yamazaki and K. Wasa, Appl. Opt., 23, 2187-91 (1984).

5) R. Takayama, Y. Tomita, K. Iijima and I. Ueda, J. Appl. Phys., 63, 5868-72 (1988).

6) K. Kushida and H. Takeuchi, Appl. Phys. Lett., 50, 1800-01 (1987).

7) K. Iijima, Y. Tomita, R. Takayama and I. Ueda, J. Appl. Phys., 60, 361-67 (1986).

8) T. Terashima, K. Iijima, K. Yamamoto, Y. Bando and H. Mazaki, Jpn.J. Appl. Phys., 27, L 91-93 (1988).

9) T. Terashima, Y. Bando, K. Iijima, K. Yamamoto and K. Hirata, Appl. Phys. Lett., 53, 2232-34 (1988). 